\title{
Uridine supplementation with Mitocnol antagonizes antiretroviral nucleoside analogue-induced mitochondrial peripheral and cerebral neuropathy in vivo
}

\author{
D Lebrecht ${ }^{1}$, C Deveaud ${ }^{2}$, B Beauvoit ${ }^{2}$, J Bonnet ${ }^{2}$, J Kirschner ${ }^{3}$, K Mueller ${ }^{4}$, \\ N Venhoff*1 and UA Walker ${ }^{1}$
}

\begin{abstract}
Address: ${ }^{1}$ University Hospital Freiburg/Dept. Rheumatology and Clinical Immunology, Freiburg, Germany, ${ }^{2}$ Institut de Biochimie et de Génétique Cellulaires, UMR 5095 CNRS-Université Victor Ségalen Bordeaux cedex, Bordeaux, France, ${ }^{3}$ University Hospital Freiburg/Department of

Neuropediatrics and Muscle Disorders, Freiburg, Germany and ${ }^{4}$ University Hospital Freiburg/Department of Neuropathology, Freiburg, Germany

* Corresponding author
\end{abstract}

from Ninth International Congress on Drug Therapy in HIV Infection

Glasgow, UK. 9-13 November 2008

Published: 10 November 2008

Journal of the International AIDS Society 2008, I I (Suppl I):PI48 doi:I0.I I86/I758-2652-I I-SI-PI 48

This abstract is available from: http://www.jiasociety.org/content/I I/SI/PI48

(c) 2008 Lebrecht et al; licensee BioMed Central Ltd.

\section{Purpose of the study}

Peripheral neuropathy and CNS neurodegeneration may be a toxic effect of some antiretroviral nucleoside analogues on mitochondria. We investigated if this neuropathology may be antagonized by uridine supplementation in vivo.

\section{Methods}

BalbC mice ( 7 weeks of age) were fed with zalcitabine (13 $\mathrm{mg} / \mathrm{kg} / \mathrm{d})$ or zidovudine $(100 \mathrm{mg} / \mathrm{kg} / \mathrm{d})$ with or without Mitocnol (340 mg/kg/d) a dietary supplement with high uridine bioavailability for 9 weeks. Hippocampus and ischiadic nerve ultrastructure and mitochondrial functions were assessed.

\section{Summary of results}

Zalcitabine and to a lower extent zidovudine induced a significant peripheral and cerebral neuropathy with disrupted mitochondrial architecture, depleted mitochondrial DNA (mtDNA), and reduced levels of cytochrome Coxidase activity (COX) and mtDNA-encoded cytochrome C subunit I (COX I). Mitocnol had no side-effects but attenuated or fully normalized all pathology of the peripheral and central nervous system (Table 1).

\section{Conclusion}

Zidovudine and zalcitabine induce a mitochondrial peripheral and cerebral neuropathology, both of which are antagonized by Mitocnol. 
Table I:

\begin{tabular}{|c|c|c|c|c|c|c|}
\hline & Control & Mitocnol & $\begin{array}{l}\text { Zidovudine } \\
(100 \mathrm{mg} / \mathrm{kg} / \mathrm{d})\end{array}$ & $\begin{array}{l}\text { Zidovudine (100 mg/ } \\
\text { kg/d) + Mitocnol }\end{array}$ & $\begin{array}{l}\text { Zalcitabine } \\
\text { (13 mg/kg/d) }\end{array}$ & $\begin{array}{l}\text { Zalcitabine (13 mg/ } \\
\text { kg/d) + Mitocnol }\end{array}$ \\
\hline \multicolumn{7}{|l|}{ Ischiadic nerve } \\
\hline mtDNA copies $\ddagger$ & $374 \pm 49$ & $372 \pm 38$ & $290 \pm 65^{*}$ & $346 \pm 35 \dagger$ & $237 \pm 6 I^{* *}$ & $335 \pm 48^{*} \dagger$ \\
\hline \multicolumn{7}{|l|}{ Hippocampus } \\
\hline mtDNA copies $\ddagger$ & $211 \pm 51$ & $219 \pm 80$ & $104 \pm 32 * *$ & $145 \pm 21{ }^{*} \dagger$ & $|5| \pm 30 *$ & $181 \pm 53^{*}$ \\
\hline coX activity @ & $11 \pm 3$ & $9 \pm 3$ & $4 \pm 2^{* *}$ & $6 \pm 2^{* * \dagger}$ & $5 \pm 2 * *$ & $8 \pm 3^{*}+$ \\
\hline COX/SDH-ratio \% & $100 \pm 9$ & $107 \pm 9$ & $48 \pm 19 * *$ & $90 \pm 18+\dagger$ & $50 \pm 15^{* *}$ & $92 \pm 20+\dagger$ \\
\hline Citrate activity @ & $1152 \pm 20 \mid$ & $1086 \pm 179$ & $1124 \pm 275$ & $1265 \pm 314$ & $|79| \pm 33^{*}$ & $1361 \pm 173 * t$ \\
\hline $\begin{array}{l}\text { COX II/COX IV- } \\
\text { ratio \% }\end{array}$ & $100 \pm 5$ & $122 \pm 26$ & $57 \pm 25^{* *}$ & $89 \pm 22 \dagger$ & $45 \pm 20 * *$ & $94 \pm 20+\dagger$ \\
\hline
\end{tabular}

*, $p<0.05$ vs. controls; $\nmid$ vs. no Mitocnol. **, $\mathrm{p}<0.001$ vs. control; $\nmid \dagger$ vs. no Mitocnol; \%, of control; $\ddagger$, copies/nucleus; @, $\mu \mathrm{moles} / \mathrm{min} / \mathrm{g}$ protein.

Publish with Bio Med Central and every scientist can read your work free of charge

"BioMed Central will be the most significant development for disseminating the results of biomedical research in our lifetime. "

Sir Paul Nurse, Cancer Research UK

Your research papers will be:

- available free of charge to the entire biomedical community

- peer reviewed and published immediately upon acceptance

- cited in PubMed and archived on PubMed Central

- yours - you keep the copyright 